\title{
Salmonella in Fish and Fishery Products
}

\author{
İlkan Ali Olgunoğlu \\ University of Adiyaman \\ Vocational School of Kahta \\ Turkey
}

\section{Introduction}

With more than 30.000 known species, fish form the biggest group in the animal kingdom that is used for the production of animal-based foods. About 700 of these species are commercially fished and used for food production. Further, some 100 crustacean and 100 molluscan species (for example mussels, snails and cephalopods) are processed as food for humans in fish industry (Oehlenschläger \& Rehbein, 2009). However, some fishery product is processed in a modern fish industry which is a technologically advanced and complicated industry in line with any other food industry, and with the same risk of product being contaminated with pathogenic organisms (Huss, 1994).

The vast majority of outbreaks of food-related illness are due to pathogenic microorganisms, rather than to chemical or physical contaminants. As they are generally undetectable by the unaided human senses (i.e.they do not usually cause colour changes or produce off-flavours or taints in the food) and they are capable of rapid growth under favourable storage conditions (Lelieveld et al. 2003). The United States Centers for Disease Control and Prevention reported that fish and shellfish account for $5 \%$ of the individual cases and $10 \%$ of all foodborne illness outbreaks, with most of the outbreaks resulting from the consumption of raw molluscan shellfish (Flick, 2008).

Salmonella is responsible for more than 40.000 cases of food-borne illness every year. The incidence of Salmonella infections has risen dramatically since the 1980s, leading to high medical costs, a loss of wages for workers who become ill, and a loss of productivity for the companies whose workers do become ill. In all, these financial losses can cost more than $\$ 3.6$ billion each year. Salmonella infections have long been a concern to scientists, doctors, and the U.S. Food and Drug Administration (FDA) (Brands, 2006). Salmonella is causing a public health problem associated with fish and fishery products. A monitoring of Salmonella has been suggested as a measure of fish quality. Also, risk management decisions should take into account the whole food chain from primary production to consumption, and should be implemented in the context of appropriate food safety infrastructures, for instance regulatory enforcement, food product tracing and traceability systems. In the fish processing chain managing risks should be based on scientific knowledge of the microbiological hazards and the understanding of the primary production, processing and manufacturing technologies and handling during food preparation, storage and transport, retail and catering (Popovic et al., 2010). Their presence in fish and fishery product is therefore seen as a sign of poor standards of process hygiene and sanitation (Dalsgaard, 1998). 


\section{Description of Salmonella}

Salmonella is a member of the Enterobacteriaceace, Gram negative, motile, with peritrichous flagella and nonsporeforming rods (the rods are typically $0.7-1.5 \mu \mathrm{m} \times 2.5 \mu \mathrm{m}$ in size). Salmonella is a facultatively anaerobic (can grow with or without oxygen) catalase positive and oxidase negative bacteria. However, Salmonella is not included in the group of organisms referred to as coliforms (Huss \& Gram, 2003; Adams \& Moss, 2005; Erkmen, 2007; Lawley et al., 2008). These mesophilic organisms are distrubuted geographically all over the world, but principally occurring in the gastrointestinal tracts of mammals, reptiles, birds, and insects and environments polluted with human or animal excreta (Huss, 1994, Huss \& Gram, 2003; Saeed \& Naji 2007). Survival in water depends on many parameters such as biological (interaction with other bacteria) and physical factors (temperature). More than 2,500 different types of Salmonella exist, some of which cause illness in both animals and people. Some types cause illness in animals but not in people. The various forms of Salmonella that can infect people are referred to as serotypes, which are very closely related microorganisms that share certain structural features. Some serotypes are only present in certain parts of the world (Brands, 2006). For over 100 years Salmonella have been known to cause illness. The bacterium was first isolated from pigs suffering hog cholera by an American scientist, Dr. Daniel Elmer Salmon, in 1885 (Bremer et al., 2003).

\section{Sources of Salmonella contamination in fish and fishery products}

Aquatic environments are the major reservoirs of Salmonella. Therefore, fishery products have been recognized as a major carrier of food-borne pathogens (Kamat et al., 2005; Upadhyay et al., 2010).

Pathogenic bacteria associated with fish and fishery product can be categorised into three general groups: (1) bacteria (indigenous bacteria) that belong to the natural microflora of fish (Clostridium botulinum, pathogenic Vibrio spp., Aeromonas hydrophila); (2) enteric bacteria (nonindigenous bacteria) that are present due to fecal contamination (Salmonella spp., Shigella spp., pathogenic Escherichia coli, Staphylococcus aureus); and (3) bacterial contamination during processing, storage or preparation for consumption (Bacillus cereus, Listeria monocytogenes, Staphylococcus aureus, Clostridium perfringens, Salmonella spp.) (Lyhs 2009).

Information from literature indicates that fresh fish, fish meal, oysters, farmed and imported frozen shrimp and froglegs can carry Salmonella sp., particularly if they are caught in areas contaminated with faecal pollution (prior to harvest and during harvest) or processed, packed, stored, distributed under unsanitary conditions and consumed raw or slightly cooked (Kumar et al., 2003; Kamat et al., 2005, Mol et al., 2010; Norhana et al., 2010).

There are some pathways of contamination of aquaculture systems with Salmonella.

\section{Non-point water run-off}

During rainfall events, increased run off of organic matter into ponds may occur and can contaminate the aquaculture system.

Animals (domestic animals, frogs, rodents, birds, insects, reptiles, etc.)

A variety of animal waste has been shown to be potential sources of Salmonella. Animal waste can be introduced directly through bird droppings or frogs living in ponds or indirectly through runoff. 


\section{Fertilization of ponds}

In some aquaculture systems animal manures are used in ponds to stimulate the production of algae. The use of non-composted manures can lead to production systems being contaminated with Salmonella.

\section{Contaminated feed}

Improperly stored feed or feed prepared on a farm under poor hygienic conditions can be a source of Salmonella.

\section{Contaminated source water}

The water used in growout ponds, cages or tanks can be contaminated with Salmonella through wildlife runoff, untreated domestic sewage, discharge from animal farms, etc.

\section{On farm primary processing}

Aquaculture products can become contaminated with Salmonella through the use of unsanitary ice, water, containers, and poor hygienic handling practices (FAO, 2010).

For example, for shrimp processing industry the information from literature indicates that the principal sources of Salmonella contamination are culture ponds, coastal water used for handling and processing of seafood (Hariyadi et al., 2005; Shabarinath et al., 2007; Upadhyay et al., 2010). Similarly, Pal and Marshall (2009) reported that the potential source of Salmonella contamination in farm-raised catfish is likely due to poor water quality, farm runoff, fecal contamination from wild animals or livestock, feed processing under poor sanitary conditions or distribution, retail marketing, and handling/preparation practices.

Ray et al.,(1976) reported that the potential hazard in cooked fishery product is cross contamination of the cooked products with raw fishery product which might occur under commercial processing condition. Thus, good sanitation practices on the unloading docks and during transport to the processing facility are essential for preventing product contamination. The use of contaminated ice or uncleaned holding facilities may also contribute to the product contaminant load (Gecan et al., 1988). As a result, many factors including inadequate supplies of clean water, inadequate sanitary measures, lack of food hygiene and food safety measures have been responsible for increased incidence of foodborne salmonellosis (Shabarinath et al., 2007).

Deep-sea fish are generally Salmonella sp. free but susceptible to contamination post-catch. Water temperature has been

proposed as playing an important role in the long-term survival of Salmonella in the environment (FAO, 2010). In raw seafood products mainly from tropical climates, there is a high prevalence of Salmonella whereas low prevalence or absence can be common in temperate regions (Millard and Rocklif, 2004).

\section{Occurrence in fish and fishery product}

Salmonella has been isolated from fish and fishery product, though it is not psychrotrophic or indigenous to the aquatic environment (Mol et al., 2010). The relationship between fish and Salmonella has been described by several scientists; some believe that fish are possible carriers of Salmonella which are harbored in their intestines for relatively short periods of time and some believe that fish get actively infected by Salmonella. The organism was never recovered from the flesh of the fish, but was isolated from viscera and epithelium (Pullela, 1997). Most outbreaks of food poisoning associated with fish derive from the consumption 
of raw or insufficiently heat treated fish and cross-contamination during processing and about $12 \%$ of the foodborne outbreaks related to consumption of fish are caused by bacteria including Salmonella (Huss et al., 2000; Aberoumand, 2010). Similarly, The U.S. Food and Drug Administration's (FDA) data showed that Salmonella was the most common contaminant of fish and fishery products (Allshouse et al., 2004). Up to 10-15\% of fish samples from India and Mexico were positive of Salmonella which has also been detected in several crustacean and molluscan products from India and Malaysia (Huss \& Gram 2003). Salmonella contamination in fish and fishery products has also been reported from other countries like Thailand, Hong Kong, Spain and Turkey (Herrera et al., 2006; Kumar et al., 2009; Pamuk et al, 2011). The highest Salmonella incidence in fishery products was determined in Central Pacific and African countries while it was lower in Europe and including Russia, and North America (Heinitz et al. 2000). For example, Davies et al. (2001) reported the absence of Salmonella in fish from European Countries such as France, Great Britain, Greece and Portugal. However, Novotny et al., (2004), reported an outbreak of Salmonella blockley infections following smoked eel consumption in Germany. Salmonella paratyphi B infections were also reported associated with consumption of smoked halibut in Germany (Da Silva, 2002). Besides, consumption of dried anchovy was found to be the cause of Salmonella infection (Ling et al., 2002).

Table 1 shows the incidence of salmonellosis associated with all food vehicles, and with separately seafood, for the European Union in 2007 (FAO,2010).

\begin{tabular}{|l|c|c|c|}
\hline \multicolumn{1}{|c|}{ Food vehicle } & $\begin{array}{c}\text { Number of } \\
\text { outbreaks }\end{array}$ & $\begin{array}{c}\text { Number of } \\
\text { Salmonella } \\
\text { outbreaks }\end{array}$ & $\begin{array}{c}\text { \% of outbreaks } \\
\text { associated with } \\
\text { Salmonella }\end{array}$ \\
\hline $\begin{array}{l}\text { Fish and fishery } \\
\text { products }\end{array}$ & 130 & 3 & 2.3 \\
\hline $\begin{array}{l}\text { Crustaceans, } \\
\text { shellfish, } \\
\text { molluscs, and } \\
\text { products }\end{array}$ & 75 & 2 & 2.7 \\
\hline All food vehicles & 2025 & 590 & 29.1 \\
\hline
\end{tabular}

Table 1. Fishery product associated outbreaks in the European Union, 2007 (Data from $\mathrm{FAO}, 2010)$

Salmonella has also been detected in US market oysters and in other US imported seafood from different countries (Heinitz et al. 2000; Ponce et al., 2008). For the 9-year period 19901999, the FDA in the United States examined imported and domestic fish and seafoods for Salmonella. Of the 11.312 imported samples, $7.2 \%$ were positive while only $1.3 \%$ of the 768 domestic samples were positive.

The most common serovar found in the world was S. Weltvreden (Heinitz et al. 2000; Jay et al., 2005). In seafood the commonest serotype encountered was S. Worthington followed by S. Weltevreden. The diversity of serovars associated with fish and fishery product was highest in Southeast Asia and next highest in South America (FAO, 2010). Most Salmonella contamination problems in fishery product associated with shrimp. Almost one-quarter of all detentions, and more than half of the violations for Salmonella, were for shrimp and prawns (farm raised and wild caught). 


\begin{tabular}{|c|c|c|c|c|c|c|c|c|c|c|}
\hline 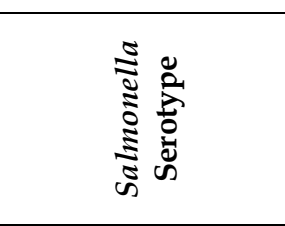 & 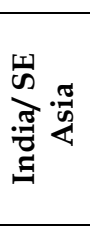 & 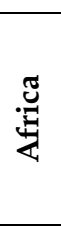 & 胥 & 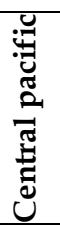 & 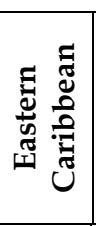 & 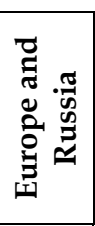 & $\frac{8}{\substack{x \\
x}}$ & 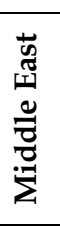 & 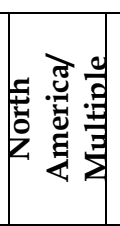 & 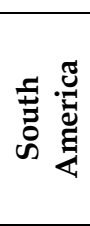 \\
\hline S. Abaetetu & & & + & & & & & & & + \\
\hline S. Aberdeen & + & & & & & & & & & \\
\hline S. Agona & + & & & & & & + & & & + \\
\hline S. Ahepe & & + & & & & & & & & \\
\hline S. Albany & + & & & & & & & & & \\
\hline S. Anatum & + & & & + & + & + & + & & & + \\
\hline S. Anfo & + & & & & & & & & & \\
\hline S. Arizonae & + & & & + & & & + & & & + \\
\hline S. Atakpam & + & & & & & & & & & \\
\hline S. Augusten & + & & & & & & & & & \\
\hline S. Baguida & & & & & & & & & & + \\
\hline S. Bareilly & + & & & & & & + & & & \\
\hline S. Biafra & + & & & & & & & & & \\
\hline S. Blockley & + & & & & & & & & & \\
\hline S. Bovis-mobificans & + & & & + & & & & & & \\
\hline S. Bradford & + & & & & & & & & & \\
\hline S. Braender & + & & & & & & & & & \\
\hline S. Brancast & + & & & & & & & & & \\
\hline S. Bredeney & & & & & & & & & & + \\
\hline S. Brunei & + & & & & & & & & & \\
\hline S. Bullbay & & & & & & & & & & + \\
\hline S. Cannstat & & & & & & & + & & & \\
\hline S. Carrau & & & + & & & & & & & \\
\hline S. Cerro & + & & & & & & & & & + \\
\hline S. Derby & + & & & + & & & & & & \\
\hline S. Drypool & + & & & & & & & & & \\
\hline S. Dublin & + & & & & & & & & & \\
\hline S. Duesseldorf & & & & + & & & & & & \\
\hline S. Emek & + & & & & & & & & & \\
\hline S. Emek & + & & & & & & & & & \\
\hline S. Enteritidis & + & + & & + & & & + & & + & + \\
\hline S. Farmsen & + & & & & & & & & & \\
\hline S. Gallinaru & + & & & & & & & & & \\
\hline S. Georgia & + & & & & & & & & & \\
\hline S. Gwaai & & & & & + & & & & & \\
\hline S. Hadar & + & & & + & & & + & + & & \\
\hline S. Harmelen & & & + & & & & & & & \\
\hline S. Havana & + & & & & + & & & & & \\
\hline S. Havana & & & & & & & & & & \\
\hline
\end{tabular}




\begin{tabular}{|c|c|c|c|c|c|c|c|c|c|c|}
\hline 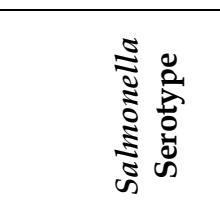 & 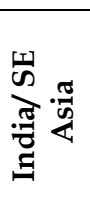 & 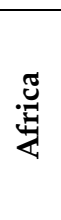 & 胥 & 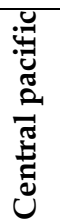 & 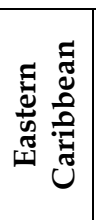 & 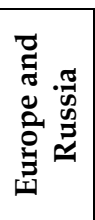 & 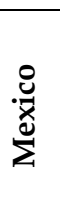 & 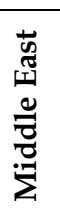 & 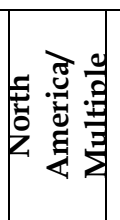 & 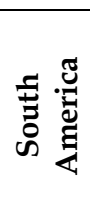 \\
\hline S. Heidelber & + & & & + & & & & & & + \\
\hline S. Hilversum & & & & + & & & & & & \\
\hline S. Houten & & & + & + & & & & & & + \\
\hline S. Houten & + & & & & & & & & & \\
\hline S. Hull & & + & & & & & & & & \\
\hline S. Hvittingfoss & + & & & & & & & & & \\
\hline S. Idikan & + & & & & & & & & & \\
\hline S. Infantis & + & & + & & + & & & & & \\
\hline S. Irumu & + & & & & & & & & & \\
\hline$S$. Isangi & + & & & & & & & & & \\
\hline S. Javiana & + & & & + & & & & & & + \\
\hline S. Kentucky & + & & & + & & & + & & & + \\
\hline S. Kirkee & + & & & & & & & & & \\
\hline S. Kottbus & + & & & & & & & & & \\
\hline S. Krefeld & + & & & & & & & & & \\
\hline S. Kumasi & + & & & & & & & & & \\
\hline S. Lanka & + & & & & & & + & & & \\
\hline S. Lansing & + & & & & & & & & & \\
\hline S. Lexington & + & & & & & & & & & \\
\hline S. Liandoff & & & & & & & + & & & \\
\hline S. Lindenburg & + & & & & & & & & & \\
\hline S. Litchfield & & & & & & & & & & + \\
\hline S. Liverpool & + & & & & & & & & & \\
\hline S. London & + & & & + & & & & & & \\
\hline S. Manila & & & & + & & & & & & \\
\hline S. Marina & & & & & & & & & & + \\
\hline S. Mbandaka & + & & + & & & & & & & \\
\hline S. Meleagridis & + & & & & & & + & & & \\
\hline S. Mendoza & & & & & & & & & & + \\
\hline S. Mgutani & + & & & & & & & & & \\
\hline S. Miami & & + & & & & & & & & \\
\hline S. Michigan & & & & & & & + & & & \\
\hline S. Minnesota & + & & & & & & + & & & \\
\hline S. Montevideo & + & & & & & & & & & \\
\hline S. Morehead & + & & & & & & & & & \\
\hline S. Mosselbay & & & & & & & & & & + \\
\hline S. Muenchen & + & & & & & & + & & & \\
\hline S. Muenster & + & & & & + & & & & & \\
\hline S. Nairobi & & + & & & & & & & & + \\
\hline
\end{tabular}




\begin{tabular}{|c|c|c|c|c|c|c|c|c|c|c|}
\hline 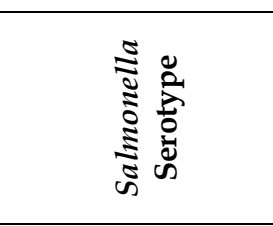 & 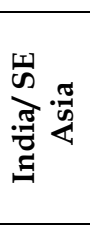 & 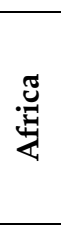 & 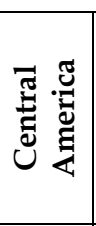 & 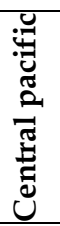 & 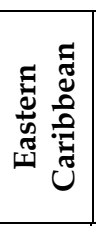 & 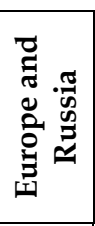 & $\frac{8}{\stackrel{0}{x}}$ & 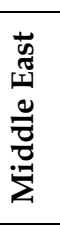 & 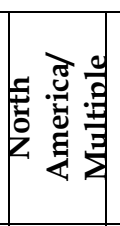 & 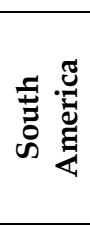 \\
\hline S. Nchanga & + & & & & & & & & & \\
\hline S. Newbrunswick & & & & & & & + & & & \\
\hline S. Newington & & & & & & & & & & + \\
\hline S. Newport & + & & + & + & & & & & + & + \\
\hline S. Ohio & + & & & & & & + & & & \\
\hline S. Onireke & & + & & & & & & & & \\
\hline S. Oranienburg & + & & & & + & & + & & & + \\
\hline S. Orientalis & & & & + & & & & & & \\
\hline S. Oslo & + & & + & & & & & & & \\
\hline S. Othmarschen & + & & & & & & & & & \\
\hline S. Panama & & & & & & & & & & + \\
\hline S. Paratyphi B & + & & & + & & & & & & \\
\hline S. Paratyphi B Java & + & & & & & & & & & \\
\hline S. Parera & & + & & & & & & & & \\
\hline S. Phoneix & & & & & & & & & & + \\
\hline S. Pomana & & & + & & & & + & & & \\
\hline S. Poona & + & & + & & & & + & & & \\
\hline S. Potsdam & + & & & & & & & & & \\
\hline S. Pullorum & & & & + & & & & & & \\
\hline S. Reading & + & & & & & & & & & \\
\hline S. Redba & & + & & & & & & & & \\
\hline S. Reinikendorf & + & & & & & & & & & \\
\hline S. Riggil & + & & & & & & & & & \\
\hline S. Rissen & + & & & & & & & & & \\
\hline S. Rubislaw & & + & + & & & & + & & & \\
\hline S. Saintpaul & + & & & + & & & + & + & + & + \\
\hline S. Saka & & + & & & & & & & & + \\
\hline S. Sandiego & + & & & & & & & & & \\
\hline S. Saphra & & & & & & & + & & & \\
\hline S. Sarajane & + & & & & & & & & & \\
\hline S. Schleisshein & + & & & & & & & & & \\
\hline \multicolumn{11}{|l|}{ S. Schwarzengrun } \\
\hline S. Senftenberg & + & & + & & + & & + & + & & \\
\hline S. Singapore & + & & & & & & & & & \\
\hline S. Srinagar & + & & & & & & & & & \\
\hline S. Stanley & + & & & + & & & & & & \\
\hline S. Takoradi & + & & & & & & & & & \\
\hline
\end{tabular}




\begin{tabular}{|c|c|c|c|c|c|c|c|c|c|c|}
\hline 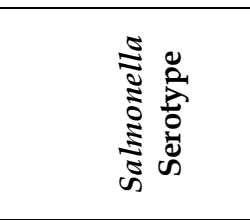 & 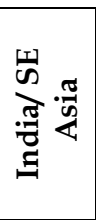 & 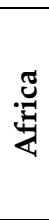 & 营 & 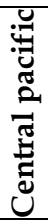 & 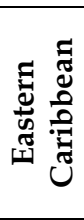 & 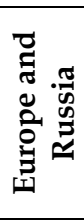 & 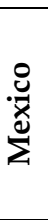 & 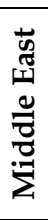 & 鹿 & 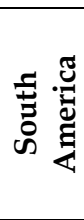 \\
\hline S. Tananarive & + & & & & & & & & & \\
\hline S. Telelkebir & & + & & & & & & & & \\
\hline S. Tennessee & + & & & & & & + & & & \\
\hline S. Thompson & + & & & + & & & + & & + & \\
\hline S. Tornow & & & & + & & & & & & + \\
\hline S. Typhi & + & & & & & & & & & \\
\hline S. Typhimurium & + & & + & & + & & + & & + & + \\
\hline S. Uganda & & & & & + & & & & & \\
\hline S. Urbana & + & & & & & & & & & \\
\hline S. Virchow & + & & & + & & & & & + & \\
\hline S. Wandsworth & + & & & & & & & & & \\
\hline S. Washington & + & & & & & & & & & \\
\hline S. Weltevreden & + & & + & + & & + & + & & & + \\
\hline S. Weston & + & & & & & & & & & \\
\hline S. Worthington & + & & & & & & & & & \\
\hline
\end{tabular}

Table 2. Salmonella serotype reported in fish and fishery products (Data from FAO, 2010)

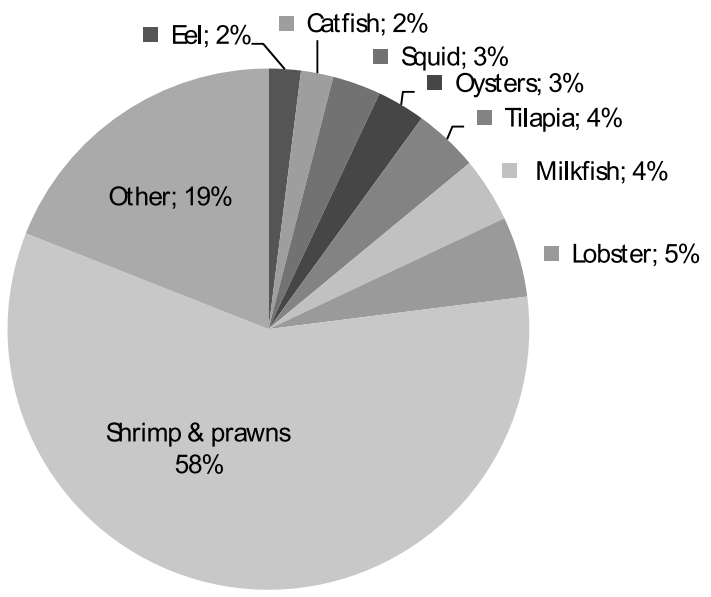

Fig. 1. Share of FDA violations for Salmonella, by fishery product, 2001 (data from Allshouse et al., 2004). 


\section{Survival and growth parameters}

Salmonella sp. can multiply and survive in the estuarine environments and tropical freshwater environments for weeks although open marine waters are free from Salmonella (Huss,1994; Huss \& Gram 2003). Salmonella prefers to grow at $37^{\circ} \mathrm{C}$. Compared to other Gram-negative bacteria, Salmonella are relatively resistant to various environmental factors. They grow at temperatures between $5^{\circ} \mathrm{C}$ and $47^{\circ} \mathrm{C}$. There are reports that they survive for longer than $E$. coli in sea and freshwater environments (Huss, 1994; Sugumar \& Mariappan, 2003; Marriot \& Gravani, 2006). Salmonella have been also reported to be able to grow within the temperature range of $2-54^{\circ} \mathrm{C}$, although growth below $7^{\circ} \mathrm{C}$ has largely been observed only in microbiological culture media and growth above $48^{\circ} \mathrm{C}$ is confined to mutants or tempered strains (Bremer et al. 2003). A few Salmonella serotypes can grow over a pH range of 3.6-9.6, which is mildly basic to strongly acidic. Optimum growth occurs at a $\mathrm{pH}$ of $6.5-7.5$, which is close to neutral. Other factors such as temperature, the type of acid present and the presence of antimicrobials can effect the minimum $\mathrm{pH}$ for growth (Brands, 2006; Marriot \& Gravani, 2006; Lawley et al., 2008). It requires a minimum Aw of 0.94 (and possibly 0.93) with a maximum salt content of $4.0 \%$ to $5.0 \%$ (Huss, 1994; Lawley et al., 2008). A study by Basti et al., (2006), for example, showed complete elimination of Salmonella on heavy salted fish and heavy salted cold smoked fish due to the high concentration levels of $\mathrm{NaCl}(>7 \%)$. Limiting conditions were summarized for Salmonella in Table 3.

\begin{tabular}{|l|c|c|c|c|c|c|c|}
\hline Pathogen & $\begin{array}{c}\text { min. Aw } \\
\text { (using salt) }\end{array}$ & $\begin{array}{c}\text { min. } \\
\mathrm{pH}\end{array}$ & $\begin{array}{c}\text { max. } \\
\mathrm{pH}\end{array}$ & $\begin{array}{c}\text { max.\% water } \\
\text { phase salt }\end{array}$ & $\begin{array}{c}\text { min. } \\
\text { temp }\end{array}$ & $\begin{array}{c}\text { max. } \\
\text { temp }\end{array}$ & $\begin{array}{c}\text { Oxygen } \\
\text { requirement }\end{array}$ \\
\hline $\begin{array}{l}\text { Salmonell } \\
\text { a spp. }\end{array}$ & 0.94 & 3.7 & 9.5 & 5 & $5{ }^{\circ} \mathrm{C}$ & $47^{\circ} \mathrm{C}$ & $\begin{array}{c}\text { facultative } \\
\text { anaerobe }\end{array}$ \\
\hline
\end{tabular}

Table 3. Limiting Conditions for Salmonella Growth

\section{Control of Salmonella in fish and fishery products}

Since most of fish products, with the exception of coldsmoked fish, sushi, and a few specialty products such as spiced, salted, or pickled fish, are expected to be cooked prior to consumption, the presence of microbiological pathogens should not present a human health hazard (Flick, 2008).

The aquaculture farm is the first link in the food safety continuum and controls must be in place and implemented throughout the food safety chain. The experts agreed that good hygienic practices during aquaculture production and biosecurity measures can minimize but not eliminate Salmonella in products of aquaculture.

Some important control measures to minimize the risk of Salmonella contamination of aquaculture products according to FAO (2011)

\section{Farm location}

- Farms should be secured from the entry of wild and domestic animals that may lead to the contamination of aquaculture products with Salmonella.

Farm layout, equipment and design

- Farm design and layout should be such that prevents cross contamination 
- $\quad$ Equipment such as cages, nets and containers should be designed and constructed to allow for adequate cleaning and disinfection

- Septic tanks, toilet facilities and bathrooms/showers should be constructed and placed so drainage does not pose a risk of contamination of farm facilities.

\section{Source water}

- Farm source water should be free from sewage contamination and suitable for aquaculture production

- Farms should have settling ponds or waste water treatment in place to condition the output water prior to discharge

\section{Ice and Water Supply}

- Potable or clean water is available and used in sufficient amount for harvest, handling and cleaning operations

- Ice should be manufactured using potable water and produced under sanitary conditions

- Ice should be handled and stored under good sanitary conditions which precludes the risk for contamination.

\section{Harvesting}

Harvesting equipment and utensils easy to clean and disinfect and kept in clean condition.

- Harvesting is planned in advance to avoid time/temperature abuse.

- Aquaculture products should be hygienically handled.

- Records on harvesting are maintained for traceability.

\section{On farm post-harvest handling}

- Utensils and equipment for handling and holding of aquaculture products is maintained in a clean condition.

- Aquaculture products are cooled down quickly and maintained at temperatures approaching that of melting ice.

- Operations such as sorting, weighing, washing, drainage, etc., are carried out quickly and hygienically.

- All additives and chemicals (disinfectants, cleaning agents, etc) used in post-harvest aquaculture products should be approved by the national competent authority.

\section{Transport of aquaculture products from farm}

- Transport is carried out in easy to clean and clean facilities (boxes, containers, etc.).

- Conditions of transport should not allow contamination from surroundings (e.g. dust, soil, water, oil, chemicals, etc.).

- Aquaculture products are transported in containers with ice or with, in sufficient amounts to ensure temperature around $0^{\circ} \mathrm{C}$ (approaching that of melting ice) in all products and during the whole period of transport.

\section{Employee health}

- Staff should be medically fit to work and should be screened regularly to determine carriers of Salmonella.

On the other hand, a number of studies have been carried out to develop methods to control contamination of proceed fishery products. They are sub-divided into physical or chemical approaches (Norhana et al., 2010). 


\section{Physical approaches}

\subsection{Cooking}

Application of heat is one of the simplest and most effective methods of eliminating pathogens from food. Heat application of $90^{\circ} \mathrm{C}$ for $1.5 \mathrm{~min}$. in the center for mollusc and 99$100^{\circ} \mathrm{C}$ for 3-4 min. for shellfish are accepted as safe processes before consumption. These temperatures are sufficient for the destruction of vegetative forms of the pathogens (Olgunoglu, 2010). Ray et al. (1976) reported that the processing of blue crabs involving steam cooking with pressure of approximately $15 \mathrm{psi}\left(121^{\circ} \mathrm{C}\right)$ for $10 \mathrm{~min}$. is sufficent to kill pathogens on the raw crab. Vegetative, unstressed Salmonella cells are heat-sensitive and are easily destroyed at pasteurisation (hot-smoking) temperatures. D-values (Decimal reduction time) at $60^{\circ} \mathrm{C}$ are typically 1-3 minutes (Huss \& Gram 2003). Time/Temperature Guidance for Controlling Salmonella growth in Fishery Products were given Table 4.

\begin{tabular}{|c|c|c|}
\hline Potentially Hazardous & Product Temperature & $\begin{array}{c}\text { Maximum Cumulative } \\
\text { Exposure Time }\end{array}$ \\
\hline Growth of Salmonella & $5.2-10^{\circ} \mathrm{C}$ & 2 days \\
species & $11-21^{\circ} \mathrm{C}$ & 5 hours \\
& above $21^{\circ} \mathrm{C}$ & 2 hours \\
\hline
\end{tabular}

Table 4. Time/Temperature Guidance for Controlling Salmonella Growth inFih and Fishery Products (FDA, 2011)

\subsection{Refrigeration}

Refrigeration and freezing are well-known techniques for extending the shelf-life of food products. These processes lower the temperature to levels at which bacterial metabolic processes are stopped and the rates of chemical and biochemical reactions reduced (Norhana et al., 2010). Although most Salmonella serotypes are unable to grow at refrigeration temperatures, the organismis can be prevented holding chilled fishery products below $4.4^{\circ} \mathrm{C}$ (Ward \&Hart, 1997). Worldwide, the most common cause of foodborne salmonellosis is Salmonella typhimurium. The minimum growth temperature reported for this species is $6.2^{\circ} \mathrm{C}$ (A study by Ingham et al., (1990), indicate that the temperature preventing growth of S. typhimurium in picked crab meat is at or below $7^{\circ} \mathrm{C}$ ). Thus, proper refrigeration will prevent growth of S. Typhimurium. However, maintenance of optimal refrigeration temperatures often cannot be guaranteed at all times prior to food consumption (Ingham et al., 1990). Thus, good sanitation after refrigeration process of fishery products such as cooked crabs or cooked shrimp are very important in maintainning product quality(Ray et al., 1976).

\subsection{Irradiation}

The irradiation of fishery products is a physical treatment involving direct exposure to electron or electromagnetic rays, for their long time preservation and improvement of quality and safety (Oraei et al., 2011; Özden \& Erkan, 2010). Irradiation of food has been legally allowed in many countries and the WHO has sanctioned radiation of up to 7.0 kilo Gray (kGy) as safe. This process is one of the most effective methods for decontaminating both the surface and deep muscle of fresh meat. There is substantial literature on the effects of irradiation in reducing Salmonella on some fishery product such as shrimp (Norhana et al., 2010). The alteration in pathogen population as a result of irradiation 
depends on the dose of irradiation, storage temperature, packaging conditions and fish species (Özden et al., 2007). For example a study, showed complete elimination of Salmonella on frozen shrimp when irradiated at $4.0 \mathrm{kGy}$. Similarly it is also reported that doses of 4.0-5.0 kGy were required to reduce the numbers of $S$. typhimurium on shrimp by $6.0 \mathrm{log}$ cycles. According to Oraei et al., (2011), low-dose gamma irradiation (especially 3 kGy) can be applied for microbial control and the safety of rainbow trout and shelf life extension in frozen state. Gamma irradiation at $3 \mathrm{kGy}$ was more effective than irradiation at 1 and $5 \mathrm{kGy}$ in eliminating microorganisms of rainbow trout fillets. The irridation doses are also reported in the range 1.5-2.0 kGy effectively control all pathogenic bacteria tested in shellfish except Salmonella spp., particularly, S. enteritidis, which requires $3.0 \mathrm{kGy}$ (IAEA,2001). Similarly to achieve safety levels against Salmonella spp., particularly $S$. enteritidis, in raw oysters, a dose of $3.0 \mathrm{kGy}$ is recommended by Gelli (2001). As a results although irradiation appears to be effective in eliminating pathogens in fishery product, there is an unsubstantiated view amongst the public that food irradiation is unsafe and undesirable. There is also evidence some that irradiation may reduce the nutritional value of some foods by the destruction of aromatic amino acids and producing rancidity and off-odours (Norhana et al., 2010).

\section{Modified atmosphere packaging (MAP)}

Modifed atmosphere packaging (MAP) has been widely used for extending the shelf life of a wide variety of food, including fish and fish products since 1980. Packages are injected with carbon dioxide, nitrogen, and very small ( 0.4 percent) amounts of carbon monoxide. The effciency of MAP in eliminating pathogens from fish depends on the gas mixture in MAP and, most importantly, the storage temperature (Redman, 2007; Hudecová et al., 2010). There is limited information on the effect of MAP with elevated $\mathrm{O}_{2}$ level on Salmonella in the literature. A study by Hudecová et al., (2010), for example, showed a signifcant decrease in the microbial growth rate on fresh chilled common carp (Cyprinus carpio) during storage at $+4 \pm 0.5{ }^{\circ} \mathrm{C}$ in two different MAP $\left(70 \% \mathrm{~N}_{2} / 30 \% \mathrm{CO}_{2}\right.$ and $\left.80 \% \mathrm{O}_{2} / 20 \% \mathrm{CO}_{2}\right)$ for 10 days when compared to air packaging and no Salmonella was reported in these conditions. Ingham et al., (1990) reported that modified atmosphere storage using $50 \% \mathrm{CO}_{2} / 10 \% \mathrm{O}_{2}$ dose effectively reduce the growth rate of $S$. typhimurium, but it cannot, in the absence of proper refrigeration, be relied upon to prevent salmonellosis.

\section{High-pressure processing (HPP) and superheated steam drying (SSD)}

High-pressure processing is an emerging non-thermal process that can be used to destroy pathogenic microorganisms in seafood without greatly affecting the quality of the product. In addition to improving the safety of shrimp, HPP has also been demonstrated to extend shrimp shelf-life. Shrimp are generally spoiled by Gram-negative bacteria, which tend to be relatively pressure sensitive due to their cell wall structure and HPP may therefore prove to be a valuable processing technology for shrimp. Although research has demonstrated the benefit of using HPP on shrimp and shrimp products, limited studies have been carried out specifically to eliminate or reduce Salmonella in fishery product using this technology.

Superheated steam drying (SSD) is a promising drying technology to a variety of industries. Superheated steam is steam heated to a temperature higher than the boiling point corresponding to its pressure (Norhana et al., 2010). 


\section{Chemical approaches}

\subsection{The use of antimicrobial agents}

Chlorine is the decontaminating agent most widely used to kill pathogenic microorganisms in the seafood industry. It is used to disinfect water used in the process (such as thawing frozen products), washing raw materials and in making ice for chilling fishery products. Commonly used chlorine compounds are liquid chlorine solution $(\mathrm{HOCl})$ and hypochlorite $(\mathrm{OCl}-)$. More recently chlorine dioxide $\left(\mathrm{ClO}_{2}\right)$ and electrolyzed oxidizing $(\mathrm{EO})$ water have also been used for this purpose. Specifically, $\mathrm{ClO}_{2}$ has been recognized as a bactericidal, viricidal and fungicidal agent and is widely used in Europe and US as an alternative to chlorine and hypochlorite. In addition, EO water has also been shown to possess strong bactericidal activity against various foodborne pathogens.

Both gaseous and dissolved forms of ozone are approved to be used as antimicrobial agents by the food industry, including the seafood industry. There are investigations on the effect of $2 \%$ ozonated saline $\left(5.2 \mathrm{mg}\right.$ ozone $\left./ \mathrm{L}, 5^{\circ} \mathrm{C}\right)$ on the inactivation of nine bacterial strains (including $S$. typhimurium) in shrimp meat. Findings showed that $S$. typhimurium was the most resistant of the species tested, with only 0.1 log cycle reductions (Norhana et al., 2010). Lactate is considered to be an effective additional hurdle against the growth of contamination flora and pathogens such as Salmonella and it is used in the further processed fish industry (fish cakes, smoked salmon, injected fillets, marinated fish). Studies on the specific action of lactates indicate they stimulate mechanisms that interfere with the metabolism of the bacteria, such as intercellular acidification and interfere with proton transfer across the cell membrane and feedback inhibition. Lactate also lowers water activity. Since lactate does not kill bacteria, it cannot be used to mask poor sanitation practices (Da Silva 2002).

\section{Intermational commision on microbiological specification for food (ICMSF) recommended microbial limits}

\begin{tabular}{|l|c|c|c|c|}
\hline \multicolumn{1}{|c|}{ Product } & \multirow{2}{*}{$\mathrm{n}^{1}$} & \multirow{2}{*}{$\mathrm{c}^{2}$} & \multicolumn{2}{c|}{ Bacteria/gram or $\mathrm{cm}^{2}$} \\
\cline { 4 - 5 } & & & $\mathrm{m}^{3}$ & $\mathrm{M}^{4}$ \\
\hline $\begin{array}{l}\text { Fresh and frozen fish and cold- } \\
\text { smoked fish }\end{array}$ & 5 & 0 & 0 & - \\
\hline Frozen raw crustaceans & 5 & 0 & 0 & - \\
\hline Frozen cooked crustaceans & 10 & 0 & 0 & - \\
\hline Fresh and frozen bivalve molluscs & 20 & 0 & 0 & - \\
\hline
\end{tabular}

${ }^{1}$ Number of representative sample units.

${ }^{2}$ Maximum number of acceptable sample units with bacterial counts between $\mathrm{m}$ and $\mathrm{M}$.

${ }^{3}$ Maximum recommended bacterial counts for good quality products.

${ }^{4}$ Maximum recommended bacterial counts for marginally acceptable quality products. Plate counts below " $\mathrm{m}$ " are considered good quality. Plate counts between " $\mathrm{m}$ " and " $\mathrm{M}$ " are considered marginally acceptable quality, but can be accepted if the number of samples does not exceed "c." Plate counts at or above "M" are considered unacceptable quality (SeafoodNIC; http://seafood.ucdavis.edu/haccp/compendium/chapt17.htm)

Table 5. Recommended microbiological limits for Salmonella spp. in fish and fishery products 


\section{Conclusions}

Significant numbers of detections of Salmonella in fish and fishery products indicate that current strategies for Salmonella control in the aquaculture production and processing sectors are not adequate. While some marine fish caught offshore and handled hygienically and at low temperature according to the Codex Code of Practice for fish and fishery products (CAC/RCP/52-2003) may be suitable for raw consumption, it would be advisable to consume products of aquaculture only after cooking. The Salmonella problem should be resolved by the use of good manufacturing procedures and the strict application of sanitary practices. On the other hand, Hazard analysis and critical control point (HACCP) systems should be implemented increasingly by private industry for seafood, sometimes voluntarily and sometimes as mandated by Federal governments. These must be rigidly enforced throughout the processing line and require the full understanding and cooperation of plant management and every employee. Investment in new technologies and equipment will also improve the seafood safety.

\section{References}

Aberoumand, A. (2010). Estimation of Microbiological Variations in Minced Lean Fish Products. World Journal of Fish and Marine Sciences, 2 (3): 204-207.

Adams M.R. \& Moss M.O. (2005). Food Microbiology Second Edition University of Surrey, Cuildford, UK. 475

Allshouse J., Buzby J., Harvey,D., Zorn D., (2004). United States Department of Agriculture Economic Research Service, Seafood Safety and Trade, Agriculture Information Bulletin, Number 789-7.

Basti, A. A.; Misaghi, A.; Salehi, T. Z. \& Kamkar A.,(2006). Bacterial pathogens in fresh ,smoked and salted Iranian fish Food Control 17: 183-188.

Brands D. A. (2006). Deadly Diseases and Epidemics Salmonella, Chelsea House Publishers, a subsidiary of Haights Cross Communications. 102p.

Bremer, P. J.; Fletcher G. C. \& Osborne, C. (2003). Salmonella in seafood. New Zealand Institute for Crop \& Food Research Limited A Crown Research Institute 4p.

CAC/RCP 52-2003 Code of Practice For Fish and Fishery Products.

Da Silva, Antonia L. V. (2002). Hazard Analysis Critical Control Point (HACCP), Microbial Safety, and Shelf Life of Smoked Blue Catfish (Ictalurus furcatus). Master of Science (M.S.) The Department of Food Science, 100p.

Dalsgaard, A. (1998). The occurrence of human pathogenic Vibrio spp. and Salmonella in aquaculture International Journal of Food Science and Technology, Volume: 33 Issue: 2 Pages: 127-138.

Davies, A. R.; Capell, C.; Jehanno, D; Nychas, G. J. E. \& Kirby, R. M. (2001). Incidence of foodborne pathogens on European fish Food Control, Volume 12, Issue 2, Pages 6771.

Erkmen O. (2007). Basic Methods for the Microbiological Analysis of Foods. Nobel Publishing, Scinece and Biology Publishing Series Publishing No:1069, Series: 29, $564 \mathrm{p}$. 
FAO (2010). Expert Workshop on the application of biosecurity Measures to control Salmonella Contamination in Sustainable aquaculture FAO Fisheries and Aquaculture Report No. 937 ISSN 2070-6987, Mangalore, India, 19-21 January 2010.

FDA. (2011). Fish\&Fisheries Products Hazards\&Control Guidance: Fourth Edition. Center for Food Safety and Applied Nutrition. Office of Seafood. 317p.

Flick, G. J.(2008). Microbiological Safety of Farmed Fish Food Safety and Technology Global Aquaculture Advocate 33-34.

Gecan, J. S.; Bandler, R. \& Atkinson J.C. (1988). Microanalytical quality of canned crabmeat, sardines and tuna. Journal of Food protection 51:12 979-981.

Gelli, D. S., Mastro, del N., Rodrigues, de M. I. \& Jakabi, M. (2001). Study on the radiation sensitivity of pathogenic Vibrionaceae and Enterobacteriaceae in vitro and after inoculation into oysters (Cassostrea brasiliana) Irradiation to control Vibrio Infection from Consumption of Raw Seafood and fresh produce Printed by the IAEA in Austria. 77p.

Hariyadi, R. D.; Nuraida, S. L. \& Fardiaz S. (2005). Determination of contamination profiles of human bacterial pathogens in shrimp obtained from Java, Indonesia. Determination of human pathogen profiles in food by quality assured microbial assays. Proceedings of a final Research Coordination Meeting held in Mexico City, Mexico, 22-26 July 2002.

Heinitz, M. L.; Ruble, R. D.; Wagner, D. E. \& Tatini, S.R. (2000). Incidence of Salmonella in fish and seafood. Journal of Food Protection 63 (5), 579-592.

Herrera, F. C.; Santos, J.A.; Oteroand, A. \& Lopez M. L. G. (2006). Occurrence of foodborne pathogenic bacteria in retail prepackaged portions of marine fish in Spain. The Society for Applied Microbiology, Journal o fApplied Microbiology 100, 527-536.

Huss, H. H. (1994). Assurance of Seafood Quality FAO Fisheries Technical Paper 334 $169 p$.

Huss, H. H.; Reilly, A. \& Embarek, P. K. B. (2000). Prevention and control of hazard in seafood. Food Control 11, 149-156.

Hudecová, K., Buchtová, H. \& Steinhauserová I. (2010). The Effects of Modifed Atmosphere Packaging on the Microbiological Properties of Fresh Common Carp (Cyprinus carpio L.) ACTA VET. BRNO 79: 93-100.

Huss, H. H. \& Gram, L. (2004). Characterization of Hazards in Seafood Assurance of Seafood Quality FAO Fisheries Technical Paper 444 227p.

IAEA (International atomic Energy) (2001). Irradiation to control vibrio infection from consumption of raw seafood and fresh produce IAEA-TECDOC-1213 Printed by the IAEA in Austria. 77p.

Ingham, S. C.; Alford, R. \& Mccown, P. (1990). Comparative growth rates of salmonella typhimurium and Pseudomonas fragi on cooked Crab meat Stored Under air and modified atmosphere. Journal of Food Protection, 53:7, 566-567.

Jay, J. M.; Loessner, M. J. \& Golden D.A. (2005). Modern Food Microbiology. Seventh Edition. Food Science Text Series. 751p. 
Kamat, A. S.; Bandekar, J. R. M.; Karani, S.; Jadhav, R.; Shashidhar, A.; Kakatkar, S.; Pingulkar, K.; Ghadge, N.; Warrier S. B. R. \& Venugopal, V. (2005). Microbiological quality of some major fishery products Exported from India. Determination of human pathogen profiles in food by quality assured microbial assays. Proceedings of a final Research Coordination Meeting held in Mexico City, Mexico, 22-26 July 2002

Kumar, S. H.; Sunil, R.; Venugopal, M. N.; Karunasagar, I. \& Karunasagar I. (2003). Detection of Salmonella spp. in tropical seafood by polymerase chain reaction. International Journal of Food Microbiology 88. 91- 95.

Kumar, R.; Surendran P. K. \&Thampuran N. (2009). Detection and characterization of virulence factors in lactose positive and lactose negative Salmonella serovars isolated from seafood. Food Control 20: 4, 376-380.

Lelieveld, H. L. M.; Unilever, R. \& Vlaardingen, D. (2009). Chaper 5. The Netherlands Sources of contamination 61-72.

Ling, M. L.; Goh, K. T.; Wang, G. C. Y.; Neo, K. S. \& Chua, T. (2002). An outbreak of multidrugresistant Salmonella enterica subsp. enterica serotype Typhimurium. Epidemiology and Infection, 128, 1-5.

Lyhs, U. (2009). Microbiological Methods, Chapter 15. Fishery Products Quality, safety and authenticity Edited by Hartmut Rehbein and Jörg Oehlenschläger (318-348).

Lawley, R., Curtis, L. \& Davis, J. (2008). The Food Safety Hazard Guidebook. Food Safety Info, London, UK RSC Publishing ISBN: 978-0-85404-460-3 422 p.

Marriot, N. G., Gravani R. B.,(2006). Principles of Food Sanitation Fifth Edition Printed in the United States of America. 413 p.

Millard, G. \& Rockliff, S. (2004). Incidence of Salmonella in Raw Fish Fillets ACT Health Protection Service

Mol, S.; Cosansu, S.; Alakavuk, D. U. \& Ozturan, S. (2010). Survivalof Salmonella enteritidis during salting and drying of horse mackerel (Trachurus trachurus) fillets. International Journal of Food Microbiology, 139: 36-40.

Norhana, M. N.W.; Poolec, S. E.; Deethah, C. \& Dykesd, G. A. (2010). Prevalence, persistence and control of Salmonella and Listeria in shrimp and shrimp products. Food Control, 21:4, 343-361.

Novotny, L.; Dvorska, L.; Lorencova, A.; Beran V. \& Pavlik I. (2004). Fish: a potential source of bacterila pathogens for human beings. Vet. Med.-Czech 49, (9): 343358.

Oehlenschläger, J. \& Rehbein, H. (2009). Basic facts and figures, Chapter 1. Fishery Products Quality, safety and authenticity Edited by Hartmut Rehbein and Jörg Oehlenschläger (1-18).

Olgunoglu, I. A. (2010). Determination of Microbiological Contamination Sources of Blue Crabmeat (Callinectes sapidus Rathbun, 1896) During Pasteurization Process. Pakistan J. Zool., vol. 42(5), pp. 545-550.

Oraei, M., Motalebi, A. A., Hoseini, E., Javan, S. 2011. Effect of Gamma irradiation and frozen storage on microbial quality of Rainbow trout (Oncorhynchus mykiss) filet. Iranian Journal of Fisheries Sciences, 10(1) 75-84. 
Özden, Ö.; Inugur, M. \& Erkan, N.( 2007). Effect of different dose gamma radiation and refrigeration on the chemical and sensory properties and microbiological status of aqua cultured sea bass (Dicentrarchus labrax). Radiation Physics and Chemistry, 76, 1169-1178.

Özden, Ö. and Erkan, N., (2010). Impacts of gamma radiation on nutritional components of minimal processed cultured sea bass (Dicentrarchus labrax). Iranian Journal of Fisheries Sciences, 9(2), 265-278.

Pal, A. \& Marshall D. L. (2009). Comparison of culture media for enrichment and isolation of Salmonella spp. from frozen Channel catfish and Vietnamese basa fillets. Food Microbiology. 26: 3, 317-319.

Pamuk, S.; Gurler, Z.; Yıldırım, Y. \& Siriken B., (2011). Detection of Microbiological Quality of common Carp (Cyprinus carpio) Sold in Public Baazar in Afyonkarahisar. Journal of Animal and Veterinary Advances, 10(8):10121018.

Ponce, E.; Khan, A. A.; Chorng-Ming, C.; Summage-West, C. \& Cerniglia, C. E. (2008). Prevalence and characterization of Salmonella enterica serovar Weltevreden from imported seafood. Food Microbiology, Volume 25, Issue 1, 29-35.

Popovic, N. T, Benussi, S. A.; Dzidara, P.; Coz-Rakovac, R.; Strunjak-Perovic, I.; Kozacinski, L.; Jadan, M. \& Brlek-Gorski, D. (2010). Microbiological quality of marketed fresh and frozen seafood caught off the Adriatic coast of Croatia. Veterinarni Medicina, 55, (5): 233-241.

Pullela, S. V. S. (1997). Aquaculture of Pacu (Piaractus mesopotamicus) and a comparison of its quality: microbiological, sensory and proximate composition. Master Of Science in Food Science and Technology. Virginia Polytechnic Institute and State University $191 \mathrm{p}$.

Ray, B., Webb, N. B. \& Speck M.L. (1976). Microbiological Evaluation of Blue crab processing operations. Journal of Food Science Volume 41, 398-402.

Redman, N. E. (2007). Food Safety, Reference Handbook Second Edition. Contemporary World Issues Series 331p.

Saeed, A. M. \& Naji, R., (2007). Infection Agents. Epidemiologic Principles and Food Safety, Edited by Tamar Lasky Oxford University Press 18-40.

SeafoodNIC (Seafood Network Information Center) (2011). Chapter 17: Salmonella, Updated: 07/18/07 http:/ / seafood.ucdavis.edu/haccp/compendium/chapt17.htm 06.06.2011

Shabarinath, S.; Kumar, H. S.; Khushiramani, R.; Karunasagar, I. \& Karunasagar, I. (2007). Detection and Characterization of Salmonella Associated with Tropical Seafood. International Journal of Food Microbiology, 114:2 227-233.

Sugumar, G. \& Mariappan, S. (2003). Survival of Salmonella sp. in Freshwater and Seawater Microcosms Under Starvation. Asian Fisheries Science, 16:247-255.

Upadhyay, B. P.; Utrarachkij, F.; Thongshoob, J.; Mahakunkijcharoen, Y.; Wongchinda, N.; Suthienkul, O. \& Khusmith S., (2010). Detection Of Salmonella inva Gene in Shrimp Enrichment Culture By Polymerase Chain Reaction. Southeast Asian J. Trop Med. Public Healt. 41: 2, 426-435. 
Ward, D. \& Hart, K. (1997). HACCP: Hazard Analysis and Critical Control Point Training Cirriculum. p. 168. Publication UNC-SG-96-02, North Carolina Sea Grant, N.C. State University, Raleigh, NC 


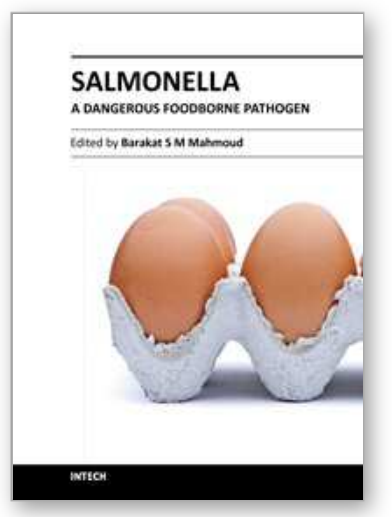

\author{
Salmonella - A Dangerous Foodborne Pathogen \\ Edited by Dr. Dr. Barakat S M Mahmoud
}

ISBN 978-953-307-782-6

Hard cover, 450 pages

Publisher InTech

Published online 20, January, 2012

Published in print edition January, 2012

More than 2,500 serotypes of Salmonella exist. However, only some of these serotypes have been frequently associated with food-borne illnesses. Salmonella is the second most dominant bacterial cause of food-borne gastroenteritis worldwide. Often, most people who suffer from Salmonella infections have temporary gastroenteritis, which usually does not require treatment. However, when infection becomes invasive, antimicrobial treatment is mandatory. Symptoms generally occur 8 to 72 hours after ingestion of the pathogen and can last 3 to 5 days. Children, the elderly, and immunocompromised individuals are the most susceptible to salmonellosis infections. The annual economic cost due to food-borne Salmonella infections in the United States alone is estimated at $\$ 2.4$ billion, with an estimated 1.4 million cases of salmonellosis and more than 500 deaths annually. This book contains nineteen chapters which cover a range of different topics, such as the role of foods in Salmonella infections, food-borne outbreaks caused by Salmonella, biofilm formation, antimicrobial drug resistance of Salmonella isolates, methods for controlling Salmonella in food, and Salmonella isolation and identification methods.

\title{
How to reference
}

In order to correctly reference this scholarly work, feel free to copy and paste the following:

Illkan Ali Olgunoğlu (2012). Salmonella in Fish and Fishery Products, Salmonella - A Dangerous Foodborne Pathogen, Dr. Dr. Barakat S M Mahmoud (Ed.), ISBN: 978-953-307-782-6, InTech, Available from: http://www.intechopen.com/books/salmonella-a-dangerous-foodborne-pathogen/salmonella-in-fish-andfishery-products

\section{INTECH}

open science | open minds

\section{InTech Europe}

University Campus STeP Ri

Slavka Krautzeka 83/A

51000 Rijeka, Croatia

Phone: +385 (51) 770447

Fax: +385 (51) 686166

www.intechopen.com

\section{InTech China}

Unit 405, Office Block, Hotel Equatorial Shanghai

No.65, Yan An Road (West), Shanghai, 200040, China 中国上海市延安西路65号上海国际贵都大饭店办公楼 405 单元

Phone: +86-21-62489820

Fax: $+86-21-62489821$ 
(C) 2012 The Author(s). Licensee IntechOpen. This is an open access article distributed under the terms of the Creative Commons Attribution 3.0 License, which permits unrestricted use, distribution, and reproduction in any medium, provided the original work is properly cited. 